\title{
COMPARISON OF FOUR HIGH THROUGHPUT SEQUENCING PLATFORMS IN A MEDICAL LABORATORY FOR GUT MICROBIOME RESEARCH ${ }^{*}$
}

\author{
P. DAS ${ }^{1}$, R. DADWAL ${ }^{1}$, V. RADHAKRISHNAN ${ }^{2}$, M. PARIHAR ${ }^{3}$, \\ S. BHATTACHARYA ${ }^{1 *}$, D. K. MISHRA ${ }^{4}$, AND M. CHANDY ${ }^{2}$ \\ ${ }^{1}$ Department of Microbiology, Tata Medical Center, Kolkata- 700 160, West Bengal, India \\ ${ }^{2}$ Department of Clinical Hematology, Tata Medical Center, Kolkata- 700 160, West Bengal, India \\ ${ }^{3}$ Department of Cytogenetics, Tata Medical Center, Kolkata- 700 160, West Bengal, India \\ ${ }^{4}$ Department of Molecular Genetics, Tata Medical Center, Kolkata- 700 160, West Bengal, India
}

\begin{abstract}
Next Generation Sequencing (NGS) systems, which are more appropriately called High Throughput Sequencing (HTS) systems have revolutionized the way microbiome of a given environment may be studied in considerable details. The reach of HTS is significantly more than that of the standards of Sanger sequencing, and the results from the study of gut microbiome and other metagenomic research has shown that HTS is going to remain as an indispensable tool for such studies for some time to come. Microbiology laboratories working in the field of human medicine, veterinary medicine, agriculture or environmental sciences would need to know and understand the intricacies of HTS methods. This would entail not only a theoretical understanding of the principles of HTS, but also a practical know how about processes, consumables, pitfalls and costs associated with HTS. The current review attempts to explain this important but complex topic with the help of a comparative description of various HTS/NGS systems available in a cancer hospital in eastern India, which is engaged in the use of such technologies for patient care and basic research.
\end{abstract}

Key words: Gut microbiome, HTS, Microbiome, Microbiota, NGS

\section{Introduction}

The human body is made up of more than 10 trillion cells and approximately 30,000 genes (Deloukas et al., 1998; Sender et al., 2016). The human microbiome consists of nearly 100 trillion microbes (Johnson and Versalovic, 2012). These microorganisms help the human body in digestion, vitamin synthesis, immune regulation and various other functions regulated by the immense microbial diversity (Rowland et al., 2018). Until about two decades back, there was no feasible way to study the microbiome of the human gut or any other natural/artificial environment. Culture-based methods are insensitive and not suitable for studying the vast diversity of microbes in the human or animal environment. The advent and rapid development of NGS technology in the last couple of decades has now enabled us to

\# Article submitted by the ALTITUDE Study Investigators group, Tata Precision Oncology program 
study the microbiome in considerable details. The terms Next Generation Sequencing (NGS) and High Throughput Sequencing (HTS) are interchangeably used; however, HTS is the technically more appropriate terminology. In this review we have used the terms as appeared in the primary reference.

\section{The difference between Sanger sequencing and Next generation sequencing (NGS)}

It is of utmost importance to understand the significant difference between Sanger sequencing and NGS. Sanger sequencing is a low throughput method to determine the nucleotide sequence of a target. It is also known by the name of di-deoxy chain termination sequencing. It is performed with capillary electrophoresis, followed by the computerized detection of the fluorescence emitted by dideoxy nucleotides (Karger and Guttman, 2009). It is known to be one of the first generation sequencing methods and commercialized by Applied Biosystems initially. Sanger sequencing works optimally for $750 \mathrm{bp}-1000 \mathrm{bp}$ genomic fragments. However, it can sequence only a single DNA fragment at a given time. Sanger sequencing is less sensitive than the NGS with a limit of detection (LOD) of $15 \%$ $20 \%$ for a mixture of DNA fragments. Sanger sequencing is relatively fast and cheaper than NGS (Tsiatis et al., 2010). The advancements in the field have enabled Sanger sequencing to sequence up to 20 samples at a time. Instead of the limitations in terms of throughput and LOD, Sanger sequencing remains the gold standard for clinical research and medical diagnostics. Sanger sequencing has been used in a variety of applications such as DNA fragment analysis, microbial identification (16S rRNA for bacteria and internal transcribed spacer, ITS for fungi), short tandem repeat (STR) analysis and even confirming the findings of NGS.

NGS, on the other hand, is a high throughput method of DNA sequencing, which is also known by the name of massively parallel sequencing or second-generation sequencing. NGS works on the principle of sequencing by ligation (SOLiD), sequencing by synthesis (Illumina) or pyrosequencing (Ambardar et al., 2016). The manufacturers such as Illumina, Thermo Fisher Scientific and Oxford Nanopore Technologies are the key players in the field of NGS. NGS is a method that can sequence millions of nucleic acid fragments simultaneously at a time. NGS technology has a LOD of about $1 \%$ for a mixture of sequences (hence known as the deep sequencing method). However, the technique of NGS is timeconsuming and not cost-effective, if the sample numbers to be processed for NGS are $<20$ (Sanger sequencing is preferred in these cases with smaller sample numbers). NGS is being applied increasingly in the clinical and research labs for whole-genome sequencing (WGS), transcriptome studies and the detection of genetic variants (Behjati and Tarpey, 2013).

\section{NGS platforms and their applications}

NGS platforms such as Ion Torrent has been applied for a variety of clinical and laboratory usage. In cancer research, it is used in liquid biopsy, targeted detection and sequencing of the oncogenes; in infectious disease and microbial research, it is used in pathogen typing, metagenomic studies, whole genome sequencing (WGS) of microorganisms and denovo sequencing. NGS has also been used in RNA sequencing, exome sequencing and targeted RNA sequencing. NGS has also been widely employed in agriculture and veterinary fields (Ambardar et al., 2016).

The Ion Torrent sequencing machines have various versions and models, which are differentiated based on the number of reads, read length, assay time and the number of sensors. The template preparation time, genetic barcode type, sequencing output, number of sequencing reads also differ between equipment 
version and NGS equipment manufacturers. Consequently, the sequencing cost of the equipment per run and the cost of sequencing per specimen varies. Comparison of MiSeq from Illumina and Ion Torrent PGM shows that the difference in the capital cost could be as much as $\$ 50,000$. One run cost is close to $\$ 1,000$ for MiSeq and $\$ 700$ for the Ion Torrent. The cost of sequencing per sample for MiSeq and Ion Torrent PGM is $\$ 60$ and $\$ 130$, respectively. This is likely to be; because the number of sequencing reads in MiSeq is about $30 \%$ more compared to that of the Ion Torrent PGM and the sequencing output is $20 \%$ more in the case of MiSeq. Sequencing output is 1.23 GB in case of MiSeq, whereas; it is only $1 \mathrm{~GB}$ in the case of Ion Torrent PGM, and reads for MiSeq and Ion Torrent are 8.16 million and 6.5 million, respectively. The template preparation time for MiSeq, is approximately 1 hour compared to 5.5 hours in the case of Ion Torrent, whereas the runtime for MiSeq is 27 hours and only 3 hours for Ion Torrent PGM (Quail et al., 2012).

\section{Pyrosequencing}

Roche diagnostics developed a system named Roche 454 GS FLX based on pyrosequencing technology. In this technology, the library preparation is performed by fragment emulsion PCR and read length is approximately similar to Sanger sequencing (750bp - 1000bp). However, the data generated per run is only $0.7 \mathrm{~GB}$ compared to $600 \mathrm{~GB}$ for a HiSeqIllumina system. The system is less often used these days despite its fast runtime and long reads because of the high error rate and high running cost (Liu et al., 2012).

\section{Comparison of various Illumina systems}

Illumina NGS machines are of various models such as MiSeq, NextSeq 500, HiSeq 2500 and HiSeqX. These versions of sequencing machines are differentiated based on various characteristics. These sequencing machines are also of various sizes and weights. The MiSeq and NextSeq approximately have dimensions of $2 \times 2 \times 2$ feet (WxHxD), whereas the HiSeq is $4 \times 2.5 \times 3$ feet in dimensions. The weight of machines may vary from $55 \mathrm{~kg}$ for MiSeq to $226 \mathrm{~kg}$ for HiSeq. These machines may have a variable number of flow cells, the number of lanes per flow cell, read length, data production per run and number of hours per run. We can observe that MiSeq can take up to 56 hours per run, NextSeq can take up to 30 hours per run, HiSeq can take up to 6 days and HiSeq $X$ can take up to 3 days for a single run. MiSeq, NextSeq, HiSeq and HiSeq $X$ are known to generate $15 \mathrm{~GB}, 120 \mathrm{~GB}, 2000 \mathrm{~GB}$ and $1800 \mathrm{~GB}$ data, respectively. The read length of these machines varies; MiSeq, NextSeq, HiSeq 2500 and HiSeq $X$ have read lengths of $300 \mathrm{bp}, 150 \mathrm{bp}, 125 \mathrm{bp}$ and $150 \mathrm{bp}$, respectively. The cluster varies from 25 million in MiSeq to 600 million in HiSeq X. In terms of applications; these machines are used for human WGS where they produce 100 GB data per sample, exon sequencing (25 million clusters per sample), bacterial WGS (0.56 GB per sample), gene expression (20 million clusters per sample) and gene panels (2 million clusters per sample).

\section{Oxford Nanopore}

The HTS instruments from Oxford Nanopore Technologies come in the following varieties: MinION and PromethION. The average read length for these machines is $900 \mathrm{~kb}$. Its output is $5 \mathrm{~GB}$ and it can produce 1 million reads. The instrument price is considerably less for MinION (\$1000) and the cost per run has been estimated to be $\$ 500-\$ 700$. In nanopore sequencing, a membrane separates two chambers containing electrolyte solution. Nanopores are present on these membranes and when a small voltage is applied across the nanopore, the current through the part can be measured. When a molecule such as a nucleic acid base passes through the nanopore, it results 
in the disruption of the ionic current. By measuring the disruption of the ionic current, the molecule is identified (Patel et al., 2018).

\section{Qiagen Gene Reader}

Qiagen Gene Reader has a high degree of automation and is used like other NGS sequencers, bioinformatics pipelines for the identification of mutations and potentially the best drugs for treatment. The steps involved in the Gene Reader system include, like others, nucleic acid extraction using kits such as Gene Reader FFPE kits, QiaSymphony and clonal amplification. NGS is performed using Gene Sequencing kits and the data analysis and interpretation are achieved by using Qiagen Clinical Insight (QCI) bioinformatics pipeline (Koitzsch et al., 2017). Quality control is performed using the DNA quantification, quality analysis kits prior to NGS.

\section{Difference between the microbiome and microbiota}

Before applying NGS in gut-microbiome studies, we need to understand the difference between microbiome and microbiota clearly. Microbiota mainly focuses on microorganisms in a particular habitat, whereas the microbiome implies the genetic makeup of the microorganisms in a specific habitat. In the broader sense, the microbiome refers to the biotic and abiotic factors within a particular environment, whereas the term microbiota is only concerned with the biotic factors (bacteriome, fungome or virome). Microbiome would be associated with genes and metabolome (Mohajeri et al., 2018).

\section{Difference between prebiotic, probiotic and postbiotic}

Prebiotics are foods, food supplements, or chemical compunds that stimulates the growth and/or activity of endogenous microbiota. Postbiotics, on the other hand, are bacterial metabolic products from endogenous microbiota that have biologic activity on the host. Probiotics are bacteria or yeasts which are said to be beneficial to the host due to its effect on attenuation of inflammation, regulation of apoptosis, promotion of intestinal barrier function. Prebiotics support probiotic growth, whereas, post-biotics mimic probiotic function. Dietary fibres are said to be rich sources of prebiotics, whereas, examples of postbiotics include short chain fatty acids. Probiotics are live micro-organisms. Synbiotics are a combination of prebiotics and probiotics. The post-biotics generated by the gut microbes are influenced by prebiotics, probiotics, synbiotics and antibiotics. Garlic, onion, honey, apples, coconut, whole grains, asparagus, leak, tomatoes are considered to be rich sources of prebiotics. Besides short chain fatty acids, vitamins, oligosachharides, polysachharides, certain proteins, enzymes and amino acids are known to be produced from the gut microbiota and act as postbiotics (Pandey et al., 2015).

\section{Human microbiome}

The human microbiome is present or divided into various body compartments such as the nose, mouth, skin, genital tracts, gastrointestinal tract etc. There are many factors which affect the microbiota and microbiome those include genetic, environmental, hormonal, drugs (antibiotics), diseases and chemicals. Many diseases cause changes or perturbation of the human microbiome and microbiota, e.g. intestinal obstruction, Clostridium difficile associated diarrhea and bacterial vaginosis etc. (Muszer et al., 2015).

\section{Microbiome in animal health}

The gastro-intestinal (GI) tract of domesticated animals such as cats and dogs have been investigated by the College of Veterinary Medicine (Texas, USA). The researchers have shown the effect of nutrition on the GI microbiome of cats and dogs. The study 
demonstrated that the presence of various proportions of carbohydrates, proteins, fats, prebiotics and probiotics affect the composition or function of the microbiome. Pet food contains substances such as beet pulp, starch, cellulose, which may differ in solubility and fermentability (de Godoy et al., 2013; Kröger et al., 2017). These differences in composition and consequently, solubilization and fermentability can affect the microbiome composition or function. Studies on pets have also demonstrated the impact of various postbiotics on pet health (Wernimont et al., 2020). Important examples include short-chain fatty acid (SCFA) acetate which acts on the neuroendocrine system; SCFA propionate affects the systemic energy availability; SCFA butyrate affects the colon and indole sulphate affects the colon and neuroendocrine system. Polyamines viz. spermidine, putrescine and cadaverine delay the intestinal epithelial senescence; hydrogen sulfide has an effect on ulcerative colitis; indoxyl-sulfate reduces kidney functions. A study from the agricultural university of Gujrat, India, characterized the microbiome of cattle using the Ion Torrent PGM platform. The taxonomic study showed that the microbiome of cattle was dominated by Bacteroidetes followed by Firmicutes, and Proteobacteria (Patel et al., 2014). Bacteroidetes, Firmicutes, Proteobacteria, Fusobacteria, Spirochaetes, Actinobacteria are the commonly found microbes from the gut of human, cat, cattle and dog (Wernimont et al., 2020).

Technologies for nucleotide sequencing and comparative sequence analysis has been in use in veterinary medicine for some time (Granberg et al, 2016). Viral diversity in swine intestinal mucus has been analysed by HTS (Dumarest et al., 2015). A study from France found Circoviridae and Parvoviridae members as the most prevalent viruses in swine intestinal mucus, together with viruses from the Picornaviridae, Astroviridae, Reoviridae, Caliciviridae,
Adenoviridae, Birnaviridae, and Anelloviridae families. Some putative new viral species were also identified by HTS (Dumarest et al., 2015). Similarly, NGS has been applied to fish ecotoxicogenomics (Mehinto et al., 2012).

Table 1 shows the various HTS platforms available at Tata Medical Centre, Kolkata. Various other HTS platforms are available from Thermo Fisher Scientific (Ion Proton, Ion PGM, Ion X5 Xl), Illumina (HiSeq 2500/3000/4000, HiSeq X, MiSeq, NextSeq and NovoSeq 5000/ 3000), Qiagen (Gene Reader) and Oxford Nanopore Technologies (MinION, Prometh ION) (Table 2). The GeneStudio S5 series machines employ various versions of Ion Chips; these versions of IonChips differ in the type of kit used, applicability in microbiome studies, targeted RNA sequencing, micro and small RNA profiling (Table 3). When comparing the limitations of the Gene Reader platform of Qiagen to the Illumina NGS system, both of them are NGS, but certain functions can be performed by only the Illumina NGS platform, e.g. Whole genome sequencing, Gene Expression analysis, micro-RNA analysis and targeted RNA sequencing and not the Gene Reader (Table 4). The NGS platforms differ in the applications, specifications, cost, read length, accuracy, dimensions, consumables, requirements, user-friendliness, runtime, weight, software used and various other parameters. The platforms iSeq, MiSeq, MiniSeq and NextSeq can be differentiated based on applications like microbial WGS, $16 \mathrm{~S}$ metagenomic sequencing, transcriptomic analysis and shotgun metagenomic sequencing (Table 5). Some of the smallest NGS platforms are available from Oxford Nanopore Technologies named MinION, PromethION and others (Table 6). These sequencers weigh less than 100gms (Flongle and MinION) and they may be powered by a laptop. The run time may be varying from 1 minute to 72 hours, depending upon the application. 
Table 1. Four major NGS manufacturers in the market with their range of NGS equipment models

\begin{tabular}{ll}
\hline Equipment manufacturer & Platform/ Model/Version \\
\hline Thermo Fisher Scientific & $\triangleright \quad$ Ion S5 XL \\
& $\triangleright \quad$ Ion Proton \\
& $\triangleright \quad$ Ion PGM \\
\hline Illumina & $\triangleright \quad$ HiSeq 2500/3000/4000 \\
& $\triangleright \quad$ MiSeq X \\
& $\triangleright \quad$ MiSeqDX/MiSeq FGX \\
& $\triangleright \quad$ NextSeq 500/550 \\
\hline Qiagen & $\triangleright \quad$ NovoSeq 5000/6000 \\
\hline Oxford Nanopore Technologies & $\triangleright \quad$ Gene Reader \\
\hline
\end{tabular}

Table 2. Comparisons of 4 different NGS technologies

\begin{tabular}{|c|c|c|c|c|}
\hline & $\begin{array}{l}\text { QIAGEN Gene } \\
\text { Reader }\end{array}$ & Illumina & $\begin{array}{l}\text { Ion GeneStudio } \\
\text { S5 System }\end{array}$ & Nanopore \\
\hline Company contact & QIAGEN & Illumina & $\begin{array}{l}\text { Thermo Fisher } \\
\text { Scientific }\end{array}$ & $\begin{array}{l}\text { Oxford } \\
\text { Nanopore } \\
\text { Technologies }\end{array}$ \\
\hline Name of instrument & $\begin{array}{l}\text { QIAGEN, Gene } \\
\text { Reader NGS } \\
\text { System }\end{array}$ & $\begin{array}{l}\text { Illumina, MiSeqDx } \\
\text { System }\end{array}$ & $\begin{array}{l}\text { Thermo Fisher } \\
\text { Scientific, Ion } \\
\text { GeneStudio S5 } \\
\text { System }\end{array}$ & MinION Mk1C \\
\hline $\begin{array}{l}\text { The country where } \\
\text { designed/ } \\
\text { manufactured/ FDA } \\
\text { cleared or approved }\end{array}$ & Germany & U.S./U.S./yes & U.S./U.S./- & UK/USA \\
\hline $\begin{array}{l}\text { First year sold in } \\
\text { U.S./Outside U.S./ } \\
\text { First year installed }\end{array}$ & $2016 / 2016 / 2015$ & $2013 / 2013 / 2013$ & $2018 / 2018 / 2018$ & $\begin{array}{l}2014 / 2015 / \\
2015\end{array}$ \\
\hline $\begin{array}{l}\text { Equipment supplied } \\
\text { with system/ } \\
\text { automation for library } \\
\text { preparation }\end{array}$ & $\begin{array}{l}\text { GeneRead } \\
\text { QIAcube for } \\
\text { clonal library } \\
\text { amplification, } \\
\text { PC work station } \\
\text { for Gene Reader, } \\
\text { power station } \\
\text { server for data } \\
\text { analysis, } \\
\text { QIAcube for } \\
\text { sample } \\
\text { extraction and } \\
\text { library } \\
\text { preparation/yes }\end{array}$ & $\begin{array}{l}\text { Single unit } \\
\text { inclusive of } \\
\text { amplification, } \\
\text { paired-end } \\
\text { sequencing/yes }\end{array}$ & $\begin{array}{l}\text { Ion GeneStudio S5 } \\
\text { sequencer/yes }\end{array}$ & $\begin{array}{l}\text { MinION Mk1C } \\
\text { with VolTRAX } \\
\text { forportable } \\
\text { sample } \\
\text { preparation, PC } \\
\text { work station }\end{array}$ \\
\hline
\end{tabular}


Cont. Table 2.

\begin{tabular}{|c|c|c|c|c|}
\hline & $\begin{array}{l}\text { QIAGEN Gene } \\
\text { Reader }\end{array}$ & Illumina & $\begin{array}{l}\text { Ion GeneStudio } \\
\text { S5 System }\end{array}$ & Nanopore \\
\hline $\begin{array}{l}\text { Necessary equipment } \\
\text { not included with the } \\
\text { system (additional } \\
\text { cost) }\end{array}$ & $\begin{array}{l}\text { Thermocycler } \\
(\sim 3,000) \text {, Qubit } \\
(\sim 2,000)\end{array}$ & $\mathrm{NA}$ & $\begin{array}{l}\text { Ion Chef System } \\
\text { for automated } \\
\text { library and } \\
\text { template prep, } \\
\text { general laboratory } \\
\text { supplies }\end{array}$ & NA \\
\hline $\begin{array}{l}\text { Bioinformatics tools } \\
\text { provided/For use by } \\
\text { biologist or } \\
\text { bioinformatician }\end{array}$ & $\begin{array}{l}\text { GeneRead Link } \\
\text { middleware, } \\
\text { QIAGEN Clinical } \\
\text { Insight Analyze, } \\
\text { QIAGEN Clinical } \\
\text { Insight } \\
\text { Interpret/biologist }\end{array}$ & $\begin{array}{l}\text { Local Run } \\
\text { Manager, MiSeq } \\
\text { Reporter, } \\
\text { BaseSpace/ } \\
\text { biologist }\end{array}$ & $\begin{array}{l}\text { Torrent Suite, Ion } \\
\text { Reporter, } \\
\text { Oncomine } \\
\text { Reporter, Torrent } \\
\text { Circuit/biologist }\end{array}$ & $\begin{array}{l}\text { EPI2ME } \\
\text { Real-time data } \\
\text { analysis } \\
\text { workflows } \\
\text { accessed } \\
\text { through the } \\
\text { cloud } \\
\text { orlocally using } \\
\text { MinION Mk1C } \\
\text { or MinIT, } \\
\text { Min KNOW } \\
\text { and Guppy also } \\
\text { for base calling }\end{array}$ \\
\hline $\begin{array}{l}\text { Supplied with UPS/ } \\
\text { entire workflow can } \\
\text { occur in the same lab }\end{array}$ & $\begin{array}{l}\text { yes (extra } \\
\text { charge)/yes }\end{array}$ & $\begin{array}{l}\text { yes (extra } \\
\text { charge)/yes }\end{array}$ & no/yes & no/yes \\
\hline $\begin{array}{l}\text { Cleanroom } \\
\text { requirements/ } \\
\text { electrical connection }\end{array}$ & $\begin{array}{l}-/ 100-240 \\
\text { VAC, 50-60 Hz }\end{array}$ & $\begin{array}{l}-100-240 \mathrm{VAC} \\
\text { at } 50-60 \mathrm{~Hz}\end{array}$ & $\begin{array}{l}\text { none/100-240 } \\
\text { VAC, 50-60 Hz, } \\
6.5-14.5 \mathrm{~A}\end{array}$ & $\begin{array}{l}\text { Supplied with } \\
\text { a } 6.3-19.6 \\
\text { VDC power } \\
\text { supplyMax } \\
\text { rated current } \\
10 \text { A Max rated } \\
\text { power } 60 \mathrm{~W}\end{array}$ \\
\hline Purchase options & $\begin{array}{l}\text { capital purchase, } \\
\text { reagent rental, } \\
\text { lease }\end{array}$ & $\begin{array}{l}\text { purchase, reagent } \\
\text { rental, lease } \\
\text { (financing } \\
\text { available) }\end{array}$ & $\begin{array}{l}\text { purchase, trade-in, } \\
\text { lease (financing } \\
\text { available) }\end{array}$ & $\begin{array}{l}\text { capital } \\
\text { purchase, } \\
\text { reagent rental, } \\
\text { lease }\end{array}$ \\
\hline Warranties offered & 1 year & $\begin{array}{l}\text { first year included } \\
\text { with purchase, } \\
\text { extended warranty } \\
\text { available }\end{array}$ & $\begin{array}{l}\text { first year included } \\
\text { with purchase, } \\
\text { extended warranty } \\
\text { available }\end{array}$ & $\begin{array}{l}\text { first year } \\
\text { included with } \\
\text { purchase, } \\
\text { extended } \\
\text { warranty } \\
\text { available } \\
\end{array}$ \\
\hline $\begin{array}{l}\text { Training included/ } \\
\text { Total time for a } \\
\text { standard installation } \\
\text { and basic training }\end{array}$ & yes/1 week & $\begin{array}{l}\text { yes/ }<1 \text { day } \\
\text { installation, }<1 \text { day } \\
\text { training }\end{array}$ & yes/1 day & $\begin{array}{l}\text { Online } \\
\text { workshop } \\
\text { (free)1 day } \\
\text { training for } \\
\text { Rapid Start } \\
\text { Day Training }\end{array}$ \\
\hline
\end{tabular}


Cont. Table 2.

\begin{tabular}{|c|c|c|c|c|}
\hline & $\begin{array}{l}\text { QIAGEN Gene } \\
\text { Reader }\end{array}$ & Illumina & $\begin{array}{l}\text { Ion GeneStudio } \\
\text { S5 System }\end{array}$ & Nanopore \\
\hline & & & & $\begin{array}{l}\text { (\$6000) 2-day training } \\
\text { in Advance Nanopore } \\
\text { Training }(\$ 15000)\end{array}$ \\
\hline $\begin{array}{l}\text { Training location/ } \\
\text { Follow-up training } \\
\text { available }\end{array}$ & on-site/yes & $\begin{array}{l}\text { on-site/yes (extra } \\
\text { charge) }\end{array}$ & $\begin{array}{l}\text { on and off-site/yes } \\
\text { (extra charge) }\end{array}$ & $\begin{array}{l}\text { Due to COVID- } \\
19, \text { training } \\
\text { packages } \\
\text { available online }\end{array}$ \\
\hline $\begin{array}{l}\text { Instrument core } \\
\text { performance } \\
\text { •Maximum number of } \\
\text { libraries amplified in } \\
\text { single amplification event }\end{array}$ & $24 \times 3$ & $\begin{array}{l}384 \text { samples } \\
\text { (>384 samples } \\
\text { with custom } \\
\text { barcodes) }\end{array}$ & $\begin{array}{l}384 \text { (with custom } \\
\text { barcodes) }\end{array}$ & $\begin{array}{l}\text { Up to } 30 \mathrm{~Gb} \text { per } \\
\text { MinION Flow } \\
\text { Cell / } 2 \text { Gb per } \\
\text { Flongle Flow Cell }\end{array}$ \\
\hline
\end{tabular}

Table 3. Different application Ion GeneStudio $\mathbf{S 5}$ series from Thermo Fisher Scientific with kit specification

\begin{tabular}{|c|c|c|c|c|c|c|c|}
\hline & Kit used & $\begin{array}{l}\text { Ion } 510 \\
\text { Chip }\end{array}$ & $\begin{array}{l}\text { Ion } 520 \\
\text { Chip }\end{array}$ & $\begin{array}{l}\text { Ion 530 } \\
\text { Chip }\end{array}$ & $\begin{array}{l}\text { Ion } 540 \\
\text { Chip }\end{array}$ & $\begin{array}{c}\text { Ion } 550 \\
\text { Chip }\end{array}$ & \\
\hline Max read size & & $3 \mathrm{M}$ & $6 \mathrm{M}$ & $20 \mathrm{M}$ & $80 \mathrm{M}$ & $130 \mathrm{M}$ & \\
\hline Targeted DNA seq* & $\begin{array}{l}\text { Ion Plus } \\
\text { Fragment } \\
\text { Library Kit }\end{array}$ & YES & YES & YES & YES & YES & \\
\hline 16S metagenomics* & $\begin{array}{l}\text { Ion 16S } \\
\text { Metagenomic kit }\end{array}$ & - & YES & YES & - & - & \\
\hline Small genome seq* & $\begin{array}{l}\text { Ion Xpress Plus } \\
\text { fragment library } \\
\text { kit }\end{array}$ & - & YES & YES & - & - & \\
\hline Exomeseq & $\begin{array}{l}\text { Ion AmpliSeq } \\
\text { Exomepannel }\end{array}$ & - & - & - & YES & & YES \\
\hline Targeted RNA seq & $\begin{array}{l}\text { Ion AmpliSeq } \\
\text { made to order } \\
\text { RNA panels }\end{array}$ & YES & YES & YES & YES & & YES \\
\hline mi RNA/small RNA profile & RNA Seq v2 kit & YES & YES & YES & - & & - \\
\hline $\begin{array}{l}\text { Low pass whole genome } \\
\text { sequencing (PGS) }\end{array}$ & $\begin{array}{l}\text { Ion reproseq } \\
\text { PGS kit }\end{array}$ & YES & YES & YES & - & & \\
\hline Targated transcriptome seq & $\begin{array}{l}\text { AmpliSeq } \\
\text { transcriptome } \\
\text { human gene } \\
\text { expression kit }\end{array}$ & - & - & - & YES & & YES \\
\hline
\end{tabular}

*Most commonly used protocol for different microbiome studies

Table 4. Limitation of the Gene Reader platform as compared to Illumina NGS systems

\begin{tabular}{lcc}
\hline & Illumina & Gene Reader NGS System \\
\hline Whole genome analysis & Yes & No \\
Gene expression analysis & Yes & No \\
Small RNA-seq, including miRNA & Yes & No \\
Targeted RNA panels & Yes & No \\
\hline
\end{tabular}


Table 5. Applications of different Illumina platforms

\begin{tabular}{|c|c|c|c|c|c|}
\hline & iSeq 100 & MiniSeq & $\begin{array}{l}\text { MiSeq } \\
\text { Series }\end{array}$ & $\begin{array}{c}\text { NextSeq } \\
550\end{array}$ & $\begin{array}{c}\text { NextSeq } \\
2000\end{array}$ \\
\hline $\begin{array}{l}\text { Small whole-genome } \\
\text { sequencing (microbe, virus) }\end{array}$ & Yes & Yes & Yes & Yes & Yes \\
\hline $\begin{array}{l}\text { Targeted gene sequencing } \\
\text { (amplicon-based, gene panel) }\end{array}$ & Yes & Yes & Yes & Yes & Yes \\
\hline $\begin{array}{l}\text { Exome and large panel } \\
\text { sequencing (enrichment-based) }\end{array}$ & - & - & - & Yes & Yes \\
\hline $\begin{array}{l}\text { Targeted gene expression } \\
\text { Profiling }\end{array}$ & - & Yes & Yes & Yes & Yes \\
\hline $\begin{array}{l}\text { 16S Metagenomic } \\
\text { sequencing }\end{array}$ & - & Yes & Yes & Yes & Yes \\
\hline $\begin{array}{l}\text { Metagenomic profiling } \\
\text { (shotgun metagenomics, } \\
\text { metatranscriptomics) }\end{array}$ & - & - & - & Yes & Yes \\
\hline
\end{tabular}

Table 6. Different format for Nanopore technologies with its utility and requirements

\begin{tabular}{|c|c|c|c|c|c|}
\hline & Flongle & MiniION Mk1B & MiniION Mk1C & GridION Mk1 & PromethION 24/48 \\
\hline Power & $\begin{array}{l}\text { Powered by } \\
\text { MinION / } \\
\text { GridION } \\
\end{array}$ & $\begin{array}{l}\text { Powered by } \\
\text { Laptop / MinIT }\end{array}$ & $25 \mathrm{~W}$ & $800 \mathrm{~W}$ & $2 \mathrm{~kW}$ \\
\hline Weight & $20 \mathrm{~g}$ & $87 \mathrm{~g}$ & $450 \mathrm{~g}$ & $11 \mathrm{~kg}$ & $\begin{array}{l}\text { Sequencer: } 28 \mathrm{~kg} \\
\text { Data Acquisition } \\
\text { Unit: } 25 \mathrm{~kg}\end{array}$ \\
\hline Run time & $1 \mathrm{~min}-16$ hours & $1 \mathrm{~min}-48$ hours & $1 \mathrm{~min}-48$ hours & 1 min - 48 hours & $1 \mathrm{~min}-72$ hours \\
\hline $\begin{array}{l}\text { Number of } \\
\text { flow cells / } \\
\text { device }\end{array}$ & 1 & 1 & 1 & 5 & $24 / 48$ \\
\hline $\begin{array}{l}\text { Software } \\
\text { License and } \\
\text { Warranty } \\
\text { annual charge }\end{array}$ & - & - & $\$ 300$ & $\$ 12500$ & $\$ 20000$ \\
\hline $\begin{array}{l}\text { Suitable } \\
\text { applications } \\
\text { include }\end{array}$ & $\begin{array}{l}\text { AmpliconsPanels/ } \\
\text { targeted } \\
\text { sequencing } \\
\text { Quality testing } \\
\text { Small } \\
\text { sequencing } \\
\text { tests }\end{array}$ & $\begin{array}{l}\text { WGS/exomes } \\
\text { Metagenomics } \\
\text { Targeted } \\
\text { sequencingWhole } \\
\text { transcriptome } \\
\text { (cDNA) } \\
\text { Smaller } \\
\text { transcriptomes } \\
\text { (direct RNA) } \\
\text { Multiplexing for } \\
\text { smaller samples }\end{array}$ & $\begin{array}{l}\text { Whole } \\
\text { genomes/exomes } \\
\text { Metagenomics } \\
\text { Targeted } \\
\text { sequencing Whole } \\
\text { transcriptome } \\
\text { (cDNA) } \\
\text { Smaller } \\
\text { transcriptomes } \\
\text { (direct RNA) } \\
\text { Multiplexing for } \\
\text { smaller samples } \\
\text { Particularly suitable } \\
\text { for field use }\end{array}$ & $\begin{array}{l}\text { Larger genomes } \\
\text { or projects } \\
\text { Whole } \\
\text { transcriptomes } \\
\text { (direct RNA or } \\
\text { cDNA) } \\
\text { Large numbers } \\
\text { of samples }\end{array}$ & $\begin{array}{l}\text { Very large genomes } \\
\text { or projects } \\
\text { Population-scale } \\
\text { human Whole } \\
\text { transcriptomes } \\
\text { Very large numbers } \\
\text { of samples }\end{array}$ \\
\hline
\end{tabular}




\section{Conclusion}

HTS platform needs to be selected after careful consideration not only because of the cost of capital and consumables but also for the compatibility with various applications, data quality and ease of use. There are many factors that need an appraisal before selecting an HTS platform. The factors that need to be considered include those related to the machine, people, material, methods and environment. Within machine factors, the laboratory needs to be very clear about the objective of HTS, sample load, budget, space availability, specific applications etc. Other important factors to be considered include the chemistry of detection, read length, number of reads per minute, throughput requirement, additional equipment required. HTS systems cannot be run without appropriate human resources who are skilled in HTS technique, data analysis and bioinformatics. With regards to the material, the laboratory needs to consider the packaging and shelf-life of the kits, pricing and vendor. Suitable kits for research use

\section{REFERENCES}

Ambardar S, Gupta R, Trakroo D, Lal R and Vakhlu J, 2016. High throughput sequencing: An overview of sequencing chemistry. Indian J Microbiol, 56(4): 394-404, doi: 10.1007/ s12088-016-0606-4

Behjati S and Tarpey PS, 2013. What is next generation sequencing? Arch Dis Child Educ Prac Ed, 98(6): 236-238, doi: 10.1136/archdischild2013-304340

Deloukas P, Schuler GD, Gyapay G, Beasley EM, Soderlund C et al., 1998. A physical map of 30,000 human genes. Science, 282(5389): 744-746, doi: 10.1126/science.282.5389.744

de Godoy MRC, Kerr KR and Fahey Jr GC, 2013. Alternative dietary fiber sources in companion animal nutrition. Nutrients, 5(8): 3099-3117, doi: 10.3390/nu5083099

Dumarest M, Muth E, Cheval J, Gratigny M, Hebert C et al., 2015. Viral diversity in swine intestinal or diagnostic applications, quality control, financial arrangements such as reagent rentals, supply chain management, compatibility with EQAS (external quality assurance scheme) and specimen compatibility must be ensured before any HTS run.With regard to the methods, one needs to identify the appropriate reference data and reference methods. The SOPs (standard operating procedures) need to determine coverage, error rates, time to result, validation, experiments, data analysis software and DNA library preparation methods.

The environment for HTS experiments needs a well defined IT (information technology) setup, data storage policy, power backup, ultra-pure water supply, sample storage policy, safety and security systems. The machine itself should be protected from temperature changes, vibrations and humidity changes. It is clear from this review that HTS is a potent tool, but the system needs to be selected after considerable review of literature, and discussion with stake holders.

mucus used for the manufacture of heparin as analyzed by high-throughput sequencing. Biologicals, 43(1): 31-36, doi: 10.1016/ j.biologicals.2014 10.004

Granberg F, Baìlint Aì and Belaìk S, 2016. Novel technologies applied to the nucleotide sequencing and comparative sequence analysis of the genomes of infectious agents in veterinary medicine. Rev Sci Tech, 35(1): 25-42, doi: 10.20506/rst.35.1.2415

Johnson CL and Versalovic J, 2012. The human microbiome and its potential importance to pediatrics. Pediatrics, 129(5): 950-960, doi: 10.1542/peds.2011-2736

Karger BL and Guttman A, 2009. DNA sequencing by capillary electrophoresis. Electrophoresis, 30(S1): S196-S202, doi: 10.1002/elps. 200900218

Koitzsch U, Heydt C, Attig H, Immerschitt I, Merkelbach-Bruse S et al., 2017. Use of the 
GeneReader NGS system in a clinical pathology laboratory: A comparative study. J Clin Pathol, 70(8): 725-728, doi: $10.1136 /$ jclinpath-2017204342

Kröger S, Vahjen W and Zentek J, 2017. Influence of lignocellulose and low or high levels of sugar beet pulp on nutrient digestibility and the fecal microbiota in dogs. J Anim Sci, 95(4): 1598-1605, doi: $10.2527 /$ jas.2016.0873

Liu L, Li Y, Li S, Hu N, He Y et al., 2012. Comparison of next-generation sequencing systems. J Biomed Biotechnol, 2012: 251364: doi: $10.1155 / 2012 / 251364$

Mehinto AC, Martyniuk CJ, Spade DJ and Denslow ND, 2012. Applications of next-generation sequencing in fish ecotoxicogenomics. Front Genet, 3: 1-10, doi: 10.3389/fgene.2012.00062

Mohajeri MH, Brummer RJM, Rastall RA, Weersma RK, Harmsen HJM et al., 2018. The role of the microbiome for human health: from basic science to clinical applications. European J Nutr, 57(S1): 1-14, doi: 10.1007/s00394-018-1703-4

Muszer M, Noszczyñska M, Kasperkiewicz K and Skurnik M, 2015. Human microbiome: when a friend becomes an enemy. Arch Immunol Ther Exp, 63(4): 287-298, doi: 10.1007/s00005-0150332-3

Pandey K, Naik SR and Vakil B, 2015. Probiotics, prebiotics and synbiotics- A review. J Food Sci Technol, 52(12), doi: 10.1007/s13197-0151921-1

Patel A, Belykh E, Miller EJ, George LL, Martirosyan NL et al., 2018. MinION rapid sequencing: review of potential applications in neurosurgery. Surg
Neurol Int, 9(1): 157, doi: 10.4103/sni.sni_55_18

Patel V, Patel AK, Parmar NR, Patel AB, Reddy B et al., 2014. Characterization of the rumen microbiome of Indian Kankrej cattle (Bos indicus) adapted to different forage diet. Appl Microbiol Biotechnol, 98(23): 9749-9761, doi: 10.1007/s00253-014-6153-1

Quail MA, Smith M, Coupland P, Otto TD, Harris SR et al., 2012. A tale of three next generation sequencing platforms: comparison of Ion Torrent, Pacific Biosciences and Illumina MiSeq sequencers. BMC Genom, 13: 341, doi: 10.1186/ 1471-2164-13-341

Rowland I, Gibson G, Heinken A, Scott K, Swann J et al., 2018. Gut microbiota functions: metabolism of nutrients and other food components. European J Nutr, 57: 1-24, doi: 10.1007/s00394-017-1445-8

Sender R, Fuchs S and Milo R, 2016. Revised estimates for the number of human and bacteria cells in the body. PLoS Biol, 14(8): e1002533, doi: 10.1371/ journal.pbio. 1002533

Tsiatis AC, Norris-Kirby A, Rich RG, Hafez MJ, Gocke CD et al., 2010. Comparison of Sanger sequencing, pyrosequencing, and melting curve analysis for the detection of KRAS mutations: diagnostic and clinical implications. J Mol Diagn, 12(4): 425-432, doi: 10.2353/ jmoldx.2010.090188

Wernimont SM, Radosevich J, Jackson MI, Ephraim E, Badri DV et al., 2020. The effects of nutrition on the gastrointestinal microbiome of cats and dogs: impact on health and disease. Front Microbiol, 11: 1266, doi: 10.3389/ fmicb.2020.01266 